DOI: 10.46340/eujem.2020.6.5.5

\author{
Oleksandr Kuchmieiev, PhD in Psychology \\ ORCID ID: https://orcid.org/0000-0003-1803-6231 \\ Open International University of Human Development "Ukraine", \\ Ukraine
}

\title{
RISK MANAGEMENT METHODOLOGY AT WHOLESALE ENTERPRISES
}

The article provides a systematic analysis of risk management methods in wholesale enterprises and recommends, along with methods of risk avoidance, localization, dissipation, and compensation, to add its adoption to the main types of risk management methods. This position is based on the fact that certain situations in wholesale trade do not provide managers with the opportunity to prevent losses, and management decisions, in this case, should be aimed at building readiness for their occurrence. General recommendations for the choice of risk management method in wholesale enterprises depending on risk factors are given. A systematized portfolio of management methods has been developed, which facilitates the manager's choice of ways and means to influence emerging risk situations. It is proposed to implement an integrated system of risk management methods at wholesale trade enterprises. Perspective directions of research of risk management at the enterprises of wholesale trade are defined.

Keywords: risk, wholesale trade enterprises, risk management system, matrix model, integrated system.

Statement of the problem. In a changing dynamic environment, wholesale enterprises, in general, always have business risks. Risk is an economic concept that reflects how stakeholders in economic relations percept objectively existing uncertainty and conflicts, inherent to the processes of goal setting, management, decision-making, and evaluation, burdened with possible threats and failed opportunities. Wholesale enterprises face a huge number of negative factors like instability of supply, late and incomplete payments by consumers, difficulties in attracting credit resources, which affect the end result of their activities - the amount of profit. The result of effective risk management determines how to obtain the economic effect for these enterprises. Thus, the issue of risk management at wholesale enterprises is quite relevant in market conditions.

Analysis of recent research and publications. Different theoretical and practical aspects of risk management at enterprises are studied in the works by such domestic and foreign authors as R.M. Kachalov and B.G. Kleiner ${ }^{1}$ who believe that the main types of risk management are methods of risk avoidance, its localization, dissipation, and compensation. A close position is supported by G.S. Tokarenko ${ }^{2}$, who offers to consider risk transferring as one of the types of risk management methods. In essence, the transferring of risk implies its transfer to another economic entity, which means the transfer of responsibility for the risk to a third party and, in our view, partially is a method of risk avoidance. The same viewpoint is supported by V.A. Uspenskyi ${ }^{3}$, who claims that to some extent all methods of risk management are aimed at minimizing it. But, following the principles of minimization, the author offers a different division of risk management methods: loss prevention, self-insurance, insurance, risk transferring, and its diversification. O.V. Raievnieva ${ }^{4}$ believes that the classification of risk management methods should be organized according to the basic laws of the management system. Accordingly, all methods can be classified as organizational (administrative), economic, and socio-psychological. More large-scale theoretical study of possible approaches to the classification of risk management methods of trade enterprises was carried out by V.A. Borovkova, whose works define up to fifteen classification features, which should contribute

\footnotetext{
${ }^{1}$ Качалов, Р. М. (2012). Управление хозяйственным риском. Москва: Наука.; Клейнер, Г. Б. (1998). Стратегии бизнеса: аналитический справочник. Москва: КОНСЭКО.

2 Токаренко, Г. С. (2016). Методы управления рисками в компании. Финансовый менеджмент, 4, 130-143.

${ }^{3}$ Успенский, В. А. (2014). Методы управления риском. Финансы и кредит, 7, 43-50.

${ }^{4}$ Раєвнєва, О. В. (2016). Управління розвитком підприємства: методологія, механізми, моделі. Харків: ІНЖЕК.
} 
to systematization and putting in order existing methodological support (by the direction of impact, source of impact, forms, scope of coverage, number of goals, depth of impact, content, duration, etc. $)^{1}$. Besides, research in this field has been carried out by other scholars as well.

Previously unsolved parts of the general problem. Despite a significant number of theoretical and practical works, scholars note that existing developments do not allow to form a systemic perception of the content of risks and their typology in wholesale trade mainly because the specifics of the industry are ignored, so nowadays it is extremely important to develop risk management methods at wholesale enterprises.

The purpose of the article is to analyze the state of risk management at wholesale enterprises, to identify its gaps and shortcomings, and to develop methods of risk management at these enterprises.

Presentation of the main research material. Risk management methods are considered in academic literature from different positions.

Substantive aspects of different types of risk management methods, presented in Table 1, give possibility to deduce that their general focus is to minimize risks and their consequences.

From our standpoint, the consideration of all management methods as a system of means to influence risks is more of a theoretical nature but really important for the development of risk management theory. Meanwhile, their simultaneous practical implementation, especially in the trade, would significantly complicate the decision-making process and provoke resistance from managers of trade enterprises.

Table 1

Typology of risk management methods

\begin{tabular}{|l|l|}
\hline \multicolumn{1}{|c|}{$\begin{array}{c}\text { Type of risk management } \\
\text { method }\end{array}$} & \multicolumn{1}{c|}{ Content } \\
\hline 1. Risk avoidance & $\begin{array}{l}\text { Deliberate refusal to make decisions that in any way will contribute } \\
\text { to the emergence of a risk situation. }\end{array}$ \\
\hline 2. Localization. & $\begin{array}{l}\text { Differentiation of the system of rights, powers, and responsibility } \\
\text { so that the consequences of the risk situation would not affect } \\
\text { the implementation of a management decision. }\end{array}$ \\
\hline 3. Dissipation. & Risk distribution between different objects. \\
\hline 4. Compensation. & $\begin{array}{l}\text { Creation of preventive conditions that exclude the emergence } \\
\text { of risk causes and factors. }\end{array}$ \\
\hline
\end{tabular}

Source: developed by the author based on sources ${ }^{2}$.

Therefore, for the development of transparent information and methodical support for risk management at wholesale enterprises, in our opinion, it is more reasonable to follow the typology of management methods by the direction of impact. But returning to its content, we see it necessary to remark that along with the methods of avoidance, localization, dissipation, and compensation of risks, it is advisable to add adoption to the main types of risk management methods. This suggestion is stipulated by the fact that certain situations in the activities of wholesale enterprises do not leave managers with opportunities other than to form readiness for risk emergence.

In order to systematize the author's suggestion to differentiate types and kinds of risk management methods at wholesale enterprises, we have developed a portfolio of management methods systematized by types, which alleviates the manager's choice of ways and means to influence emerging risk situations (Table 2).

Consequently, despite the universality of most risk management methods, each one has its own characteristic features, advantages and limitations for use in the field of wholesale trade. That is why management decision-making must be scientifically grounded to ensure the economic feasibility of the costs for the introduction of one method or another.

\footnotetext{
${ }^{1}$ Боровкова, В.А. (2014). Управление рисками в торговле. Санкт-Петербург: Питер.

${ }^{2}$ Качалов, Р. М. (2012). Управление хозяйственным риском. Москва: Наука; Клейнер, Г. Б. (1998). Стратегии бизнеса: аналитический справочник. Москва: КОНСЭКО.; Успенский, В. А. (2014). Методы управления риском. Финансы и кредит, 7, 43-50.
} 
The portfolio of risk management methods at wholesale trade systematized by types

\begin{tabular}{|c|c|}
\hline $\begin{array}{l}\text { Type of risk management } \\
\text { methods }\end{array}$ & $\begin{array}{l}\text { Types of risk management methods } \\
\text { at wholesale enterprises }\end{array}$ \\
\hline Avoidance & $\begin{array}{l}\text { Refusal to work with unreliable partners; insurance; search for guarantors; } \\
\text { limitation; implementation of control systems and partial duplication } \\
\text { of functions in the functioning of the wholesale trade enterprise. }\end{array}$ \\
\hline Localization & Outsourcing; disaggregation. \\
\hline Dissipation & $\begin{array}{l}\text { Horizontal integration with suppliers; commodity diversification; regional } \\
\text { diversification; diversification of suppliers (carriers). }\end{array}$ \\
\hline Compensation & $\begin{array}{l}\text { Strategic planning; forecasting and monitoring of the environment condition; } \\
\text { forecasting and monitoring of commodity markets; active marketing; flexible } \\
\text { pricing; self-insurance through the creation of commodity, financial, staffing } \\
\text { reserves; implementation of training and motivation programs for staff. }\end{array}$ \\
\hline Adoption & Self-insurance; incorporation of small losses into the retail price of goods. \\
\hline
\end{tabular}

Source: developed by the author based on sources ${ }^{l}$.

Identified peculiarities of the application of risk management methods in the field of wholesale trade should become the methodological basis for the choice of a method depending on risks evaluation.

However, in our opinion, it is possible to choose a relevant method of risk management considering not only the size of the expected losses but also the probability of their emergence. Some recommendations in this direction are represented in the work of V.A. Borovkova ${ }^{2}$, who has developed a general twodimensional matrix of four quadrants "the size of possible losses (large and small) - the probability of risk (high and low)".

So, to improve the risk management mechanism in the activities of wholesale trade enterprises, we have developed a set of tools, which consist of a matrix and integrated system of risk management at wholesale trade enterprises.

The essence of the matrix risk management system is presented below.

At the first stage, it is recommended to identify possible risks that may affect the activities of the wholesale enterprise in the future; with this aim, we offer to assemble an expert group chaired by the head (for example, by the senior executive officer) of a trade enterprise and to include in this group the heads of the relevant subdivisions (like commercial director, financial director, director of transportation, chief accountant, head of a legal department, director of human resources and social work, head of information and analytical department, etc.), who would bring up for discussion issues regarding possible risks that may ultimately affect the overall performance of the wholesale enterprise. The following scheme is elaborated for such discussion:

The result of risk identification is creation of their full list according to elements defined above.

At the second stage, we offer to identify the significance of the risk assessing the need to influence it; in particular, the significance of the risk is proposed to calculate using the Risk Index (RI). In risk theory, this index is calculated as the product of the value of expected losses $\left(\mathrm{V}_{\mathrm{EL}}\right)$ and the probability of their emergence $\left(\mathrm{P}_{\mathrm{E}}\right)^{3}$ :

$$
\mathrm{RI}=\mathrm{V}_{\mathrm{EL}} * \mathrm{P}_{\mathrm{E}}
$$

\footnotetext{
${ }^{1}$ Боровкова, В. А. (2014). Управление рисками в торговле. Санкт-Петербург: Питер; Еш, С. М. (2016). Фінансовий ринок. Київ: Центр учбової літератури.; Нецымайло, К. В. (2013). Методы управления рисками в деятельности субъектов малого предпринимательства. Вестник Оренбургского государственного университета, 9 (103), 46-52.

${ }^{2}$ Боровкова, В.А. (2014). Управление рисками в торговле. Санкт-Петербург: Питер, 194.

${ }^{3}$ Катилова, Н. В. (2016). Практика ключевых индикаторов для операционных рисков. Управление финансовыми рисками, 2, 45.
} 


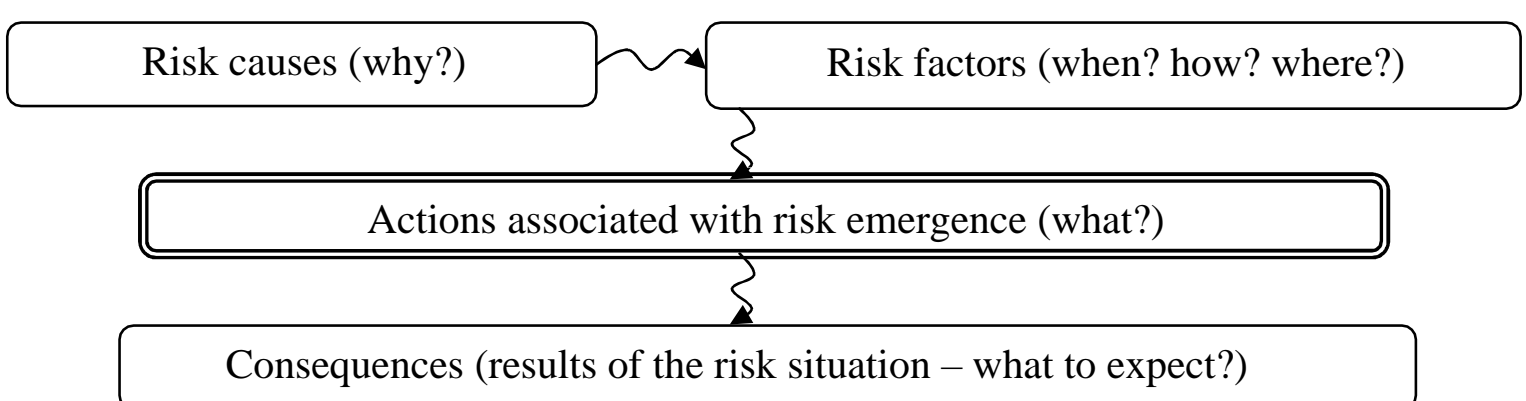

Fig.1. Basic elements of risk identification

Source: developed by the author based on sources ${ }^{l}$.

At the third stage, we suggest to define a risk level in the course of activities of the wholesale trade enterprise and to choose a relevant method of risk management; for this purpose, the following order is offered:

1. To define the level of risk by the amount of loss of expected operating profit, applying a scale: minimum (10\%), low (10-40\%), medium (60-40\%), high (60-90\%), critical (more than 90\%).

2. To ensure an expert assessment of the probability of operating profit losses applying a scale: Losses are almost impossible - 0.1; Losses are improbable (low probability) - 0.2; Losses are probable - 0,3 - 0,5; High probability $-0,5-0,7$; Losses are almost inevitable (extremely high probability) $-0,7-0,9$.

3. Using the selection matrix, to choose the type of risk management method for wholesale enterprises (Table 3): "WE losses - Probability of WE losses": Risk avoidance; Risk localization; Risk dissipation; Risk compensation; Risk adoption.

At the fourth stage, it is offered to compare values of expected losses of operating profit before and after the introduction of the chosen method $\left(\mathrm{VEL}_{b}, \mathrm{VEL}_{\mathrm{a}}\right)$ taking into account the costs for method implementation (CMI).

$$
\mathrm{VEL}_{b}-\left(\mathrm{VEL}_{\mathrm{a}}+\mathrm{CMI}\right) \geq 0
$$

In the fifth stage, it is proposed to decide whether the use of a risk management method is reasonable.

Furthermore, to organize an effective risk management process at wholesale enterprises, in our opinion, they need an appropriate integrated management system. Given that the management system, in general, is a set of elements necessary for the subject of management to influence the object of management, the risk management system at wholesale trade enterprises may be defined as a set of methods and tools (organizational, economic, technical) designed to manage risks in these enterprises. The stress made on the integration of this system requires its inclusion in the overall management system of the wholesale enterprise, when the level of risk and probability of its emergence become important criteria for management decisions, along with cost, expenses, time, and other criteria.

If, based on our study of risk management practices in wholesale enterprises, fragmentary risk detection is traditional for the industry, then in the integrated system, the risk management process in wholesale enterprises should be coordinated by the head of that company, and the task of risks identifying and minimizing becomes a part of the responsibilities of every manager. Moreover, the integrated system provides the ability to make management decisions at the tactical and strategic levels, taking into account the probability of possible losses of operating profit due to risk situations in procurement, transportation, and sales. That is, the process of risk management in wholesale enterprises should be continuous and cover all activities of the trading company.

Sure, the formation of an information database of risks and their processing requires the use of resources, including labor and financial resources, which are the most important from our point of view. Even if a trading company does not set apart the management function, the expansion of the powers of its managers will require additional time for such responsibilities.

\footnotetext{
${ }^{1}$ Машина, Н. І. (2016). Економічний ризик і методи його вимірювання: навчальний посібник. Київ: ЦУЛ.; Токаренко, Г. С. (2016). Методы управления рисками в компании. Финансовый менеджмент, 4, 130-143.; Успенский, В. А. (2014). Методы управления риском. Финансы и кредит, 7, 43-50.
} 
The matrix to select the type of risk management methods for the wholesale trade enterprise

\begin{tabular}{|c|c|c|c|c|c|}
\hline \multirow[b]{2}{*}{$\begin{array}{c}\text { The level } \\
\text { of expected } \\
\text { operating profit } \\
\text { losses }\end{array}$} & \multicolumn{5}{|c|}{ The probability of operating profit losses } \\
\hline & $\begin{array}{l}\text { Losses are almost } \\
\text { impossible }-0.1\end{array}$ & $\begin{array}{c}\text { Losses are } \\
\text { improbable (low } \\
\text { probability) } \\
-\quad 0.2\end{array}$ & $\begin{array}{c}\begin{array}{c}\text { Losses are } \\
\text { probable }\end{array} \\
-\quad 0,3- \\
0,5\end{array}$ & $\begin{array}{c}\text { High } \\
\text { probability - } \\
0,5-0,7\end{array}$ & $\begin{array}{c}\text { Losses are almost } \\
\text { inevitable } \\
\text { (extremely high } \\
\text { probability) } \\
0,7-0,9\end{array}$ \\
\hline Minimum $-10 \%$ & \multicolumn{3}{|c|}{ Risk adoption } & \multicolumn{2}{|c|}{ Risk compensation } \\
\hline Low $-10-40 \%$ & \multicolumn{2}{|c|}{ Risk adoption } & \multicolumn{3}{|c|}{ Risk compensation } \\
\hline $\begin{array}{l}\text { Medium - 40-60 } \\
\%\end{array}$ & Risk adoption & \multicolumn{3}{|c|}{ Risk compensation; Risk dissipation } & $\begin{array}{c}\text { Risk } \\
\text { compensation; } \\
\text { Risk avoidance }\end{array}$ \\
\hline High $-60-90 \%$ & $\begin{array}{c}\text { Risk } \\
\text { compensation; } \\
\text { Risk dissipation }\end{array}$ & $\begin{array}{c}\text { Risk } \\
\text { compensation; } \\
\text { Risk dissipation }\end{array}$ & \multicolumn{2}{|c|}{$\begin{array}{l}\text { Risk localization; Risk } \\
\text { dissipation }\end{array}$} & $\begin{array}{l}\text { Risk localization; } \\
\text { Risk avoidance }\end{array}$ \\
\hline $\begin{array}{l}\text { Critical - } \\
\text { more than } 90 \%\end{array}$ & $\begin{array}{c}\text { Risk } \\
\text { compensation; } \\
\text { Risk dissipation }\end{array}$ & $\begin{array}{c}\text { Risk } \\
\text { compensation; } \\
\text { Risk dissipation }\end{array}$ & $\begin{array}{c}\text { Risk } \\
\text { localization; } \\
\text { Risk avoidance }\end{array}$ & \multicolumn{2}{|c|}{ Risk avoidance } \\
\hline
\end{tabular}

Source: developed by the author based on sources ${ }^{l}$.

\section{Comparative analysis of traditional and integrated risk management systems in wholesale enterprises}

\begin{tabular}{|c|c|}
\hline \multicolumn{2}{|c|}{ Features of traditional and integrated risk management systems in wholesale trade enterprises } \\
\hline Traditional system & Integrated system \\
\hline $\begin{array}{l}\text { Fragmentary approach - each subdivision within its } \\
\text { functions independently and at its own discretion reacts to } \\
\text { emerging risks. }\end{array}$ & $\begin{array}{l}\text { Integrated approach - the process is coordinated by } \\
\text { leadership, each manager considers risk management } \\
\text { functions as part of their work. }\end{array}$ \\
\hline $\begin{array}{l}\text { Unsystematic and episodic nature - risk assessment and } \\
\text { response takes place sporadically on an intuitive basis. }\end{array}$ & $\begin{array}{l}\text { Continuity and cyclicality - the risk management } \\
\text { process is uninterrupted. }\end{array}$ \\
\hline $\begin{array}{l}\text { Detachment - attention is focused only on a particular } \\
\text { aspect of risk, which results do not affect the overall } \\
\text { planning process. }\end{array}$ & $\begin{array}{l}\text { Complexity and coordination - all types of risks are } \\
\text { studied, management decisions are coordinated with } \\
\text { the planning process. }\end{array}$ \\
\hline $\begin{array}{l}\text { Limited functions of risk management - the main functions } \\
\text { implemented within the risk management process are their } \\
\text { analysis and evaluation. }\end{array}$ & $\begin{array}{l}\text { Completeness of risk management functions - all risk } \\
\text { management functions are performed, from their } \\
\text { identification to management and control. }\end{array}$ \\
\hline
\end{tabular}

Source: developed by the author based on sources ${ }^{2}$.

Therefore, we believe, that a necessary condition for the introduction of many risk management methods in wholesale trade enterprises is the availability of sufficient financial resources, as far as the search for new suppliers, research of consumer demand, and the introduction of control systems are accompanied by certain costs.

\footnotetext{
${ }^{1}$ Успенский, В. А. (2014). Методы управления риском. Финансы и кредит, 7, 43-50.

${ }^{2}$ Боровкова, В. А. (2014). Управление рисками в торговле. Санкт-Петербург: Питер; Качалов, Р. М. (2012). Комплексное управление хозяйственным риском. Имущественные отношения в Российской федерации, 11 (62), 3-10; Нецымайло, К. В. (2013). Методы управления рисками в деятельности субъектов малого предпринимательства. Вестник Оренбургского государственного университета, 9 (103), 46-52.
} 
Conclusions. It has been substantiated that the quality and result of risk management in wholesale enterprises largely depend on the extent to which the selected management methods correspond to the risk factors identified during stages of analysis and evaluation. In order to systematize risk management methods at the above enterprises, their main types (avoidance, localization, dissipation, compensation, and adoption) have been studied, their content determined, and a portfolio of methods prioritized for management decisions in the field of wholesale trade formed.

The variety and diversity of risk management methods in the field of wholesale trade have necessitated the development of matrix and integrated models for the selection of risk management methods in wholesale enterprises, based on a five-level linguistic and scoring scale to assess the level and probability of loss of operating profit. The generalization of the author's approaches regarding the selection of risk management methods in wholesale enterprises is proposed on the basis of a structural-logical model of management decision-making, which takes into account the level of risk by the amount of operating profit losses and the probability of their emergence, and allows substantiating the selected method of risk management by comparing the expected profit losses with the costs for the method's implementation.

For the purpose of ensuring the effectiveness of the developed academic and methodological approaches, the introduction of an integrated risk management system at wholesale enterprises is suggested, which would ensure the continuity, cyclicality, complexity, and completeness of the functions of such management.

One of the most potential fields of research on this issue is the definition of integrated indicators to assess the quality of the risk management system in wholesale trade enterprises.

\section{References}

1. Borovkova, V. A. (2014). Upravlenye ryskamy v torhovle [Risk management in trading]. Saint Petersburg: Pyter. [in Russian].

2. Esh, S. M. (2016). Finansovyi rynok [Financial market]. Kyiv: CUL. [in Ukrainian].

3. Katylova, N. V. (2016). Praktyka kliuchevykh yndykatorov dlia operatsyonnykh ryskov [Practice of key indicators for operational risks]. Upravlenye fynansovymy ryskamy [Financial risk management], 2, 86-100. [in Russian].

4. Kachalov, R. M. (2012). Upravlenye khoziaistvennym ryskom [Business risk management]. Moscow: Nauka. [in Russian].

5. Kachalov, R. M. (2012). Kompleksnoe upravlenye khoziaistvennym ryskom [Comprehensive business risk management]. Ymushchestvennye otnoshenyia v Rossyiskoi federatsyy [Property relations in the Russian Federation], 11 (62), 3-10. [in Russian].

6. Mashyna, N. I. (2016). Ekonomichnyi ryzyk i metody yoho vymiriuvannia: navchalnyi posibnyk [Economic risk and methods of its measurement: a textbook]. Kyiv: CUL. [in Ukrainian].

7. Netsymailo, K. V. (2013). Metody upravlenyia ryskamy v deiatelnosty subektov maloho predprynymatelstva [Risk management methods in the activities of small businesses]. Vestnyk Orenburhskoho hosudarstvennoho unyversyteta [Bulletin of the Orenburg State University], 9 (103), 46-52. [in Russian].

8. Raievnieva, O. V. (2016). Upravlinnia rozvytkom pidpryiemstva: metodolohiia, mekhanizmy, model [Enterprise development management: methodology, mechanisms, models]. Kharkiv: INZhEK. [in Ukrainian].

9. Kleiner, H. B. (1998). Stratehyy byznesa: analytycheskyi spravochnyk [Business Strategies: An Analytical Handbook]. Moscow: KONSEKO. [in Russian].

10. Tokarenko, H. S. (2016). Metody upravlenyia ryskamy v kompanyy [Risk management methods in the company]. Fynansovyi menedzhment [Financial management], 4, 130-143. [in Russian].

11. Uspenskyi, V. A. (2014). Metody upravlenyia ryskom [Risk management techniques]. Fynansy i kredyt [Finance and credit], 7, 43-50. [in Russian]. 